\title{
CHARCOALIFIED WOOD FROM THE CENOMANIAN OF GARD (SOUTHERN FRANCE): AN INSIGHT INTO EARLY ANGIOSPERM PALAEOECOLOGY
}

\author{
Vincent GIRARD $1,2 *$, Marc PHILIPPE 3 , Marion \\ BAMFORD ${ }^{4}$, Bernard GOMEZ $Z^{3}$ \& Serge FERRY $Y^{3}$ \\ ${ }^{1}$ Centre de Bio-Archéologie et d'Ecologie (UMR 5059 CNRS/Université Mon- \\ tpellier 2/EPHE/INRAP), Institut de Botanique, 163 Rue Auguste Broussonet, \\ 34090 Montpellier, France; vicent.girard@univ-montp2.fr \\ ${ }^{2}$ Université Montpellier 2, Place Eugène Bataillon, 34095 Montpellier, France \\ ${ }^{3}$ Université Lyon 1, UMR 5276 CNRS (LGL-TPE), 43, Boulevard du 11 Nov- \\ embre 1918, F-69622 Villeurbanne Cedex, France; marc.philippe@univ-lyon1. \\ fr; bernard.gomez@univ-lyon1.fr; serge.ferry@univ-lyon1.fr \\ ${ }^{4}$ BPI Palaeontology, School of Geosciences, University of the Witwatersrand, P, \\ Bag 3, WITS 2050, Johannesburg, South Africa; marion.bamford@wits.ac.za \\ * Corresponding author
}

Girard, V., Philippe, M., Bamford, M., Gomez, B. \& Ferry, S. 2012. Charcoalifi ed wood from the Cenomanian of Gard (southern France): an insight into early angiosperm palaeoecology. [Carbón del Cenomaniense de Gard (sur de Francia): paleoecología de las primeras fl oras de angiospermas]. Revista Española de Paleontología, 27 (1), 29-44. ISSN 0213-6937.

\begin{abstract}
The discovery in the Cenomanian (early Late Cretaceous) of Southern France of several localities with abundant charcoal has brought to light several angiosperm wood types. This is the oldest angiosperm wood assemblage discovered yet for Europe. Here we analyse this assemblage, with emphasis on features recognized to be of particular palaeoecological and climatic signifi cance for the Cainozoic according to earlier studies and comparing the inferred results to those from other independent lines of evidence (sedimentology, palynology, isotopic geochemistry, etc.). Vessel diameter and distribution, perforation plates, abundance of vascular tracheids and of septate fi bres, presence of diffuse axial parenchyma perhaps should not be used as palaeoecological proxies for the Cretaceous because they do not seem to clearly correlate with other lines of evidence that indicate warm tropical conditions. The abundance of fibre-tracheids fi ts with the other sources of data, but our results are probably biased by preservation problems. On the contrary, the occurrence of growth-rings, porosity, vessel density, occurrence of vessel groups, occurrence of vasicentric tracheids and of some paratracheal to vasicentric and banded axial parenchyma correlate well with other palaeoclimate indicators. These results show that these features can be used for palaeoclimatological inferences during the early Late Cretaceous.
\end{abstract}

Keywords: Angiosperm woods, Lower Cenomanian, paleoecological reconstruction, phylogenetic bias.

\section{RESUMEN}

El hallazgo de varias localidades con abundantes depósitos de carbón en el Cenomaniense (Cretácico tardío) del sur de Francia, evidencia la presencia de varios tipos de madera de angiospermas. Esta es la asociación más antigua de maderas de angiospermas descubierta hasta ahora en Europa. Se analiza esta asociación, seleccionando los caracteres reconocidos que tengan algún particular signifi cado paleoecológico y climático, de acuerdo con estudios anteriores y comparando los resultados inferidos con evidencias proporcionadas por otras líneas independientes de investigación (sedimentología, palinología, geoquímica isotópica, etc.). Caracteres como el diámetro y distribución de los vasos, tipos de placas de perforación, abundancia de traqueidas vasculares y fibras septadas, presencia de parénquima axial difusa no pueden ser utilizados como indicadores paleoecológicos debido a que no muestran una correlación clara con otras líneas de evidencia. La abundancia de fi bro-traqueidas se ajusta con las otras fuentes de datos, pero estos resultados están sesgados por problemas de preservación. Por el contrario, la presencia de anillos de crecimiento, tipo de porosidad, la densidad de vasos, la presencia de vasos agrupados, 
de traqueidas vasicéntricas y de alguna parénquima axial paratraqueal a vasicéntrico y en bandas se correlaciona bien con otros indicadores paleoclimáticos. Estos resultados muestran que estas características pueden ser usadas para realizar inferencias paleoclimáticas durante el Cretácico tardío.

Palabras claves: Maderas de angiospermas, Cenomaniense inferior, reconstrucción paleoecológica, sesgos filogenéticos.

\section{INTRODUCTION}

No angiosperm wood record predating the Aptian has yet been found (Crawley, 2001; Philippe et al., 2008). The wood Aptiana radiata Stopes is the only Aptian angiosperm wood described so far, but its age is questionable and it likely is younger (Crawley, 2001). By the Albian, angiosperm wood is found worldwide including the morphogenera Icacinoxylon Shilkina and Paraphyllanthoxylon Bailey (Suzuki, 1982; Wheeler, 1991; Anderberg et al., 2002; Barale et al., 2002; Takahashi \& Suzuki, 2003). Nevertheless, angiosperm woods are exceedingly rare in the Albian, and it is only during the Cenomanian that both the number of angiosperm wood species and the proportion of angiosperm wood in fossil assemblages increased significantly (Gryc et al., 2009; Wheeler \& Lehman, 2009). In the Iberian Peninsula, only few and badly preserved angiosperm woods have been reported from the Upper Cretaceous (De la Fuente et al., 2008), within the Cenomanian of Segovia area. The sudden increase in the angiosperm wood record by the mid Cretaceous is striking. Why was angiosperm wood unrecorded before the Aptian, while pollen grains, leaves and even delicate flowers of early flowering plants were described from many continents (Wing \& Boucher, 1998; Willis \& McElwain, 2002; Friis et al., 2006)? Is it simply a taphonomical bias or a more complex and hidden history? Were the earliest angiosperms woody? Was the angiosperm ecology before the Albian such that the wood had little chance to fossilize? These are questions that have puzzled palaeontologists for many years. A detailed palaeoecological study of the mid Cretaceous wood record would contribute to a better understanding of the factors that led to angiosperm wood becoming more frequent among fossil assemblages by the Albian and subsequently.

For a long time it has been recognized that early angiosperm wood is difficult to assign to living families (Bailey, 1924; Page, 1979, 1980, 1981; Wheeler \& Baas, 1991). Thus palaeoecological reconstructions based on Cretaceous angiosperm wood can appear precarious when they are only based on hypothetical systematic affinities and the assumption of uniformitarism. Nevertheless palaeoecological reconstructions could be based on anatomical wood features and on the tight statistical correlations between environmental conditions and the abundance of specific anatomical characters of angiosperm woods (Upchurch \& Wolfe, 1987; Wheeler \& Baas, 1991, 1993; Wie- mann et al., 1998, 1999; Poole, 2000; Sakala, 2000; Poole \& Van Berghen, 2006).

Charcoals are one of the most common remains in the fossil record (Sander \& Gee, 1990), but there are relatively few studies of angiosperm charcoals. Xylologists mainly studied permineralized wood specimens because they generally have a larger size. This bias towards silicified wood is particularly problematic in the case of the study of early angiosperms. Indeed these early angiosperms probably did not develop thick woody logs before the mid Late Cretaceous (Philippe et al., 2008) whereas large logs are much more resistant to degradation and do become silicified (Buurman, 1972). Moreover silicification occurs in a narrow range of environmental conditions (Siurek et al., 2004) and so indicates a strong palaeoecological constraint for the corresponding wood record (Herendeen, 1991). Charcoals can be formed in a broader range of environments and are thus more informative than silicified woods for interpreting palaeoenvironments.

Here, the potential use of mid Cretaceous charcoalified angiosperm wood for palaeoecological reconstruction is demonstrated. The anatomical features of an angiosperm charcoal assemblage from the Cenomanian of Gard (SE France) is studied, without any hypothesis about their systematic relationships. Palaeoecological inferences using Wheeler \& Baas' (1991) correlations between anatomical wood characters and ecology are established. These are compared with the palaeoenvironments and the palaeoclimate of the source area at that time as deduced from sedimentology, palynology and isotopic geochemistry.

\section{GEOLOGICAL AND PALAEOCLIMATIC SETTINGS}

Angiosperm wood specimens studied herein were collected at about $40 \mathrm{~km}$ northeast of the city Nîmes, in the Gard, southeastern France (Fig. 1). Although fossil wood from there was mentioned by Pruvost (1942) and Defretin (1943), this is the first time that angiosperm wood is described from the Cenomanian of southeastern France. Specimens were embedded in siliceous limestones bearing lignite lenses, a local facies formerly named Pauletian (Ducreux, 1982) and dated Lower to Middle Cenomanian. These strata represent margino-littoral sediments, deposited in the western part of the Vocontian basin (Ducreux, 1982). At that time, the Durancian isthmus separated the 


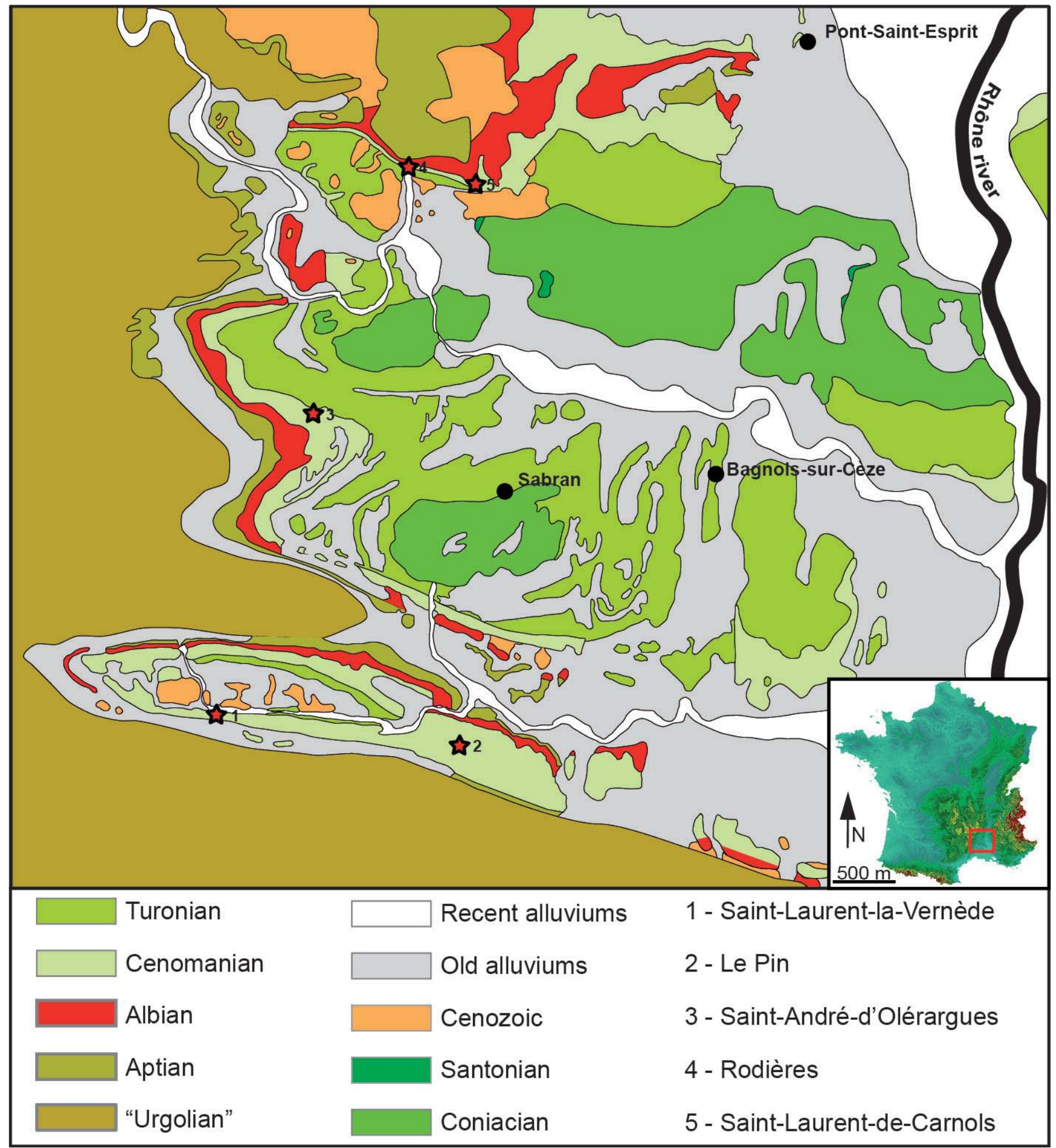

Figure 1. Simplified geological map of the studied area.

Vocontian basin and the south Provençal basin. Important siliciclastic inputs occurred north of the studied area (present day Ardèche) and were driven southward by the western Vocontian coastal current. During the Lower Cenomanian this resulted in the installation of a coastal spit at the level of the present day Rhône valley. The spit pro- tected the Gard area, and paralic sediments were deposited (Pauletian facies; Ducreux, 1982).

Ducreux (1982) interpreted the lenticular disposition of the Pauletian lignite deposits as puddle infillings, typical of marsh or lagoon environments. This interpretation is also supported by our observations of slickenslides (interpreted 
as evidence of vertisols), of clayey palaeosoils (with in situ roots) and flaser beddings. During the Early Cenomanian a lagoon isolated by a sandy coastal spit developed in the Gard, and was progressively filled. Thus tropophilous marshes or lagoons could develop in which plant debris and fine-grained sediments accumulated. Occasionally storms or sea level oscillations caused flash-flooding, intercalating lumachelic shell layers with much marine to brackish water bivalve and gastropod debris, especially in the northern part of the study area. These shelly deposits suggest more marine influence in the north compared to the south of the lagoon.

Neither typical fluvial sediments nor evidence of hydrodynamism were identified during the field survey, making it very probable that plant deposits were mostly autochthonous to parautochthonous; that means the materials were locally accumulated. This is supported by the frequent occurrence of intermingled palaeosoils and in situ root systems. In conclusion, the Pauletian palaeoflora was not a true terrestrial phytocoenosis but rather grew up in and around a lagoon or marsh.

At most localities exposure is limited and it is very difficult to accurately correlate the beds into a general stratigraphic sequence. Pauletian facies were deposited from the Albian to the Upper Cenomanian based on micropalaeontological and palynological dating (Ducreux, 1989). Based on sequence-stratigraphic correlation, the age of our charcoalified materials ranges from the LowerMiddle Cenomanian.

From various geochemical, isotopical and sedimentological evidence, the Cenomanian climate is considered to have been the warmest in recent Earth history, with terrestrial temperatures $6-12^{\circ} \mathrm{C}$ warmer than present (Sellwood et al., 1993). Voigt et al. (2003) estimated the sea surface temperature in Europe during the mid Cretaceous: they calculated $25^{\circ} \mathrm{C}$ in Spain (sea temperature) while that surrounding England was only $19^{\circ} \mathrm{C}$. Over the northwestern Tethys rim the climate was tropical (Pucéat et al., 2003; Amiot et al., 2004) with marked hydrologic seasonality over western Europe (White et al., 2001; Donnadieu et al., 2006). Some palynological investigations (Gaillard, 1982) proposed a climate with rigorous winters for the Cenomanian in the Gard. This however contrasts with other evidence that indicates a tropical climate, probably with hydric seasonality (Ducreux, 1982; Videt, 2004). Studying the black shales of the neighbouring Vocontian basin, Herrle et al. (2003a, b) and Bornemann et al. (2005) suggested that a monsoonal climate system predominated during the mid Cretaceous in western Europe. As only one study suggested a cold climate, the hypothesis of a warm tropical to sub-tropical climate with possible hydric seasonality is retained for this study.

For more information about the studied area, see Pruvost (1942), Ducreux (1982, 1989), Gaillard (1982), and Ducreux \& Gaillard (1986).

\section{MATERIALS AND METHODS}

Charcoals collected from seven localities were examined, but only five provided angiosperm woods. These five localities (Fig. 1) contained fusain as well as other plant remains (e.g., palynomorphs, cuticles, and amber).

Fusain is defined as lignified tissues transformed in a dull, fibrous, pulverulent coal, leaving a black dust on fingers and looking like charcoal (Duparque, 1926). Although production processes for charcoal are always questionable, wildfires are considered to be the major source of charcoal (Herendeen, 1991). Under anoxic conditions, temperatures between $200-400^{\circ} \mathrm{C}$ induce partial carbonization that prevents decay, limits compaction, and preserves anatomical structures (Scott, 1990; Herendeen, 1991).

Charcoal is usually collected as small pieces, of which the origin is questionable (branch, trunk or root, mature or immature wood). Because of variable anisotropic shrinkage and allometric modifications induced by charring (Slocum et al., 1978; Prior \& Gasson, 1993; Figueiral, 1999; Figueiral et al., 2002; Gerards et al., 2007), Wiemann et al.'s $(1998,1999)$ quantitative correlations could not be used, and only a qualitative approach was made. Nonetheless the cells were measured to complete the descriptions. These charcoals were not identified to existing morphogenera because of the limited number of features visible in these small wood fragments under Scanning Electronic Microscope (SEM).

The five localities from which we collected angiosperm charcoals are Saint-André-d'Olérargues, Saint-Laurent-laVernède, Le Pin, Rodières, Saint-Laurent-de-Carnols (Fig. 1). Some large $(>2 \mathrm{~cm})$ fragments were collected in the field but most of the specimens were obtained by bulk maceration of the sediments in $\mathrm{H}_{2} \mathrm{O}_{2}$ followed by rinsing in tap water through 5-mm, 2-mm, and 1-mm-mesh stainless steel sieves. After drying in a laboratory oven, charcoals were sorted under a stereomicroscope (Wild M3Z) to separate angiosperm woods from other wood types. Sixty supposed specimens were selected and pasted with ordinary glue on aluminum stubs and coated with gold/vanadium for 4.5 minutes at $25 \mathrm{eV}$ in a cathode sputtering Balzers machine. All examinations were performed at the "Centre Technologique des Microstructures - Université Lyon 1 (Claude Bernard)" under a SEM Hitachi S-800. Software analySIS was used to acquire more than 400 microphotographs. SEM observations showed that, among the 60 pre-sorted samples, only 19 have an angiopermous origin. For these charcoals the occurrence of nineteen wood anatomical features was scored (Table 1). These features have been chosen on the model of characters used by Suzuki et al. (1996) in a study of Cretaceous angiosperm wood.

Studies by Wheeler \& Baas $(1991,1993)$ and by Wiemann et al. $(1998,1999)$ based on Late Cretaceous and Cainozoic materials demonstrated that some features of secondary xylem in dicotyledonous woods are closely co- 
Table 1. The nineteen different xylological characters taken into account.

\begin{tabular}{|c|c|}
\hline $\begin{array}{l}\text { Xylological } \\
\text { characters }\end{array}$ & Observation \\
\hline General description & Type of wood porosity \\
\hline Vessel & $\begin{array}{l}\text { Presence or absence of vessel clusters } \\
\text { or radial multiples } \\
\text { Orientation of the vessels } \\
\text { Type of perforation plates } \\
\text { Presence or absence of helical } \\
\text { thickening } \\
\text { Type of intervessel pits } \\
\text { Mean diameter of vessels } \\
\text { Density of vessels (number per } \mathrm{mm}^{2} \text { ) }\end{array}$ \\
\hline Fibres & $\begin{array}{l}\text { Type of fibres } \\
\text { Type and size of pits }\end{array}$ \\
\hline Axial parenchyma & $\begin{array}{l}\text { Distribution } \\
\text { Abundance }\end{array}$ \\
\hline Rays & $\begin{array}{l}\text { Width measured in number of cells } \\
\text { Distribution: presence or absence of a } \\
\text { special arrangement of the rays } \\
\text { Height measured in number of cells } \\
\text { Homogeneity: presence of one or } \\
\text { several types of cells per ray } \\
\text { Shape of the cells (upright, square or } \\
\text { procumbent) } \\
\text { Density (number per } \mathrm{mm}^{2} \text { ) } \\
\text { Types of pits (vessel-ray pits or ray- } \\
\text { ray pits) }\end{array}$ \\
\hline
\end{tabular}

rrelated to climate but these relationships were not applied to Cretaceous floras as they were for the Cenozoic. The correlations between wood anatomical features of Mesozoic angiosperms and palaeoenvironmental factors are still incompletely known.

Data obtained from our study were analysed to determine whether similar correlations existed for a period as old as the Cenomanian. By comparing palaeoecological inferences obtained from charcoal with those obtained with other methods (geochemistry, palynology, sedimentology), each xylological feature was analysed to determine whether it could be considered as (1) climatic proxy, (2) ecological proxy or (3) unsuitable for our purpose.

\section{RESULTS}

Among the sixty charcoal specimens prepared for SEM examinations, only nineteen show clear affinities with angiosperms. They are not evenly distributed in the five lo- calities; the percentage of angiosperms in the wood assemblage varies from 1.1 to $9.5 \%$ (Table 2).

Table 2. Proportions in angiosperm charcoals in the different localities studied.

\begin{tabular}{|c|c|c|c|c|c|c|}
\hline & \multicolumn{2}{|c|}{$\begin{array}{l}\text { Saint-André- } \\
\text { d'Olérargues }\end{array}$} & \multirow{2}{*}{$\begin{array}{c}\text { Saint- } \\
\text { Laurent- } \\
\text { la- } \\
\text { Vernède }\end{array}$} & \multirow[b]{2}{*}{ Le Pin } & \multirow[b]{2}{*}{ Rodières } & \multirow{2}{*}{$\begin{array}{l}\text { Saint- } \\
\text { Laurent- } \\
\text { de- } \\
\text { Carnols }\end{array}$} \\
\hline & $\begin{array}{l}\text { lower } \\
\text { lignitic } \\
\text { clay }\end{array}$ & $\begin{array}{l}\text { upper } \\
\text { lignitic } \\
\text { clay }\end{array}$ & & & & \\
\hline $\begin{array}{l}\text { Number of } \\
\text { examined } \\
\text { charcoals }\end{array}$ & 166 & 95 & 135 & 21 & 25 & 90 \\
\hline $\begin{array}{l}\text { Angiosperm } \\
\text { charcoals }\end{array}$ & 8 & 3 & 3 & 2 & 2 & 1 \\
\hline $\begin{array}{l}\text { Percentage } \\
\text { of } \\
\text { angiosperms }\end{array}$ & 4.8 & 3.2 & 2.2 & 9.5 & 8.0 & 1.1 \\
\hline
\end{tabular}

Among these nineteen specimens, ten groups were recognized. It cannot be ascertained whether the ten morphological types correspond to ten wood morphospecies because only small wood fragments were examined. That also means that it was not possible to determine whether or not these samples correspond to any previously described woods. The descriptions given below only include the features positively determined. Nevertheless the anatomical wood diversity is relatively and unexpectedly high.

Morphotype A (Figs 2A-C)

Locality: Saint-André-d'Olérargues

Specimen numbers: AWSE-0001; AWSE-0016; AWSE0020

Description: Growth ring boundaries are indistinct or absent and wood diffuse-porous (Fig. 2A). Vessels are mainly solitary, some pairs, with scalariform perforation plates of 10-25 bars (Fig. 2B). There are two sizes of vessels: small vessels $25-30 \mu \mathrm{m}$ in diameter, and large and slightly flattened vessels $70-100 \times 100-130 \mu \mathrm{m}$ in diameter. Intervessel pits are small and alternate $(4 \mu \mathrm{m}$ in diameter). Vessel density is greater than 40 vessels per $\mathrm{mm}^{2}$. Fibres have thin walls and simple pits. In longitudinal section spiral thickening of vascular tracheids can be seen. Axial parenchyma is rare, mainly diffuse. Rays are very low, possibly only up to three cells high, and 1-2 seriate. Vessel-ray pits are simple and opposite (Fig. 2C).

Morphotype B (Figs 2D-F)

Locality: Saint-André-d'Olérargues

Specimen numbers: AWSE-0002; AWSE-0004; AWSE0013

Description: Growth ring boundaries are indistinct or absent and wood diffuse-porous (Fig. 2D). Vessels are mainly solitary, rarely in radial multiples of $2-3$, with simple perforation plates (Fig. 2E). Intervessel pits are small 

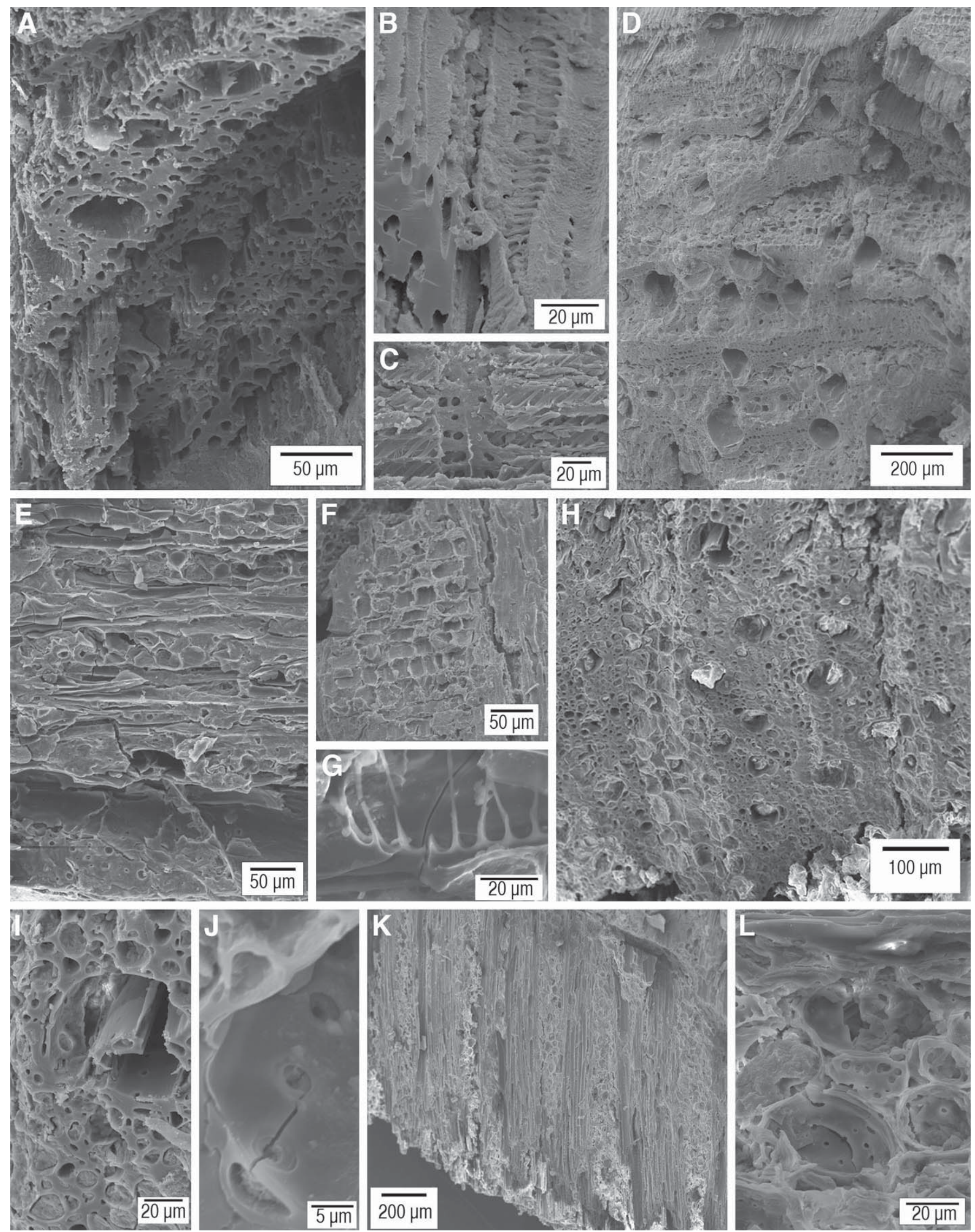
and opposite (4 $\mu \mathrm{m}$ in diameter). Mean vessel diameter is $80-120 \mu \mathrm{m}$ but some vessels are as small as $30 \mu \mathrm{m}$, a density of 15-20 vessels per $\mathrm{mm}^{2}$ was observed. Fibres have simple pits $5 \mu \mathrm{m}$ in diameter and are thin-walled. Axial parenchyma is rare and diffuse. Rays are 1-3 seriate (Fig. 2E), 2-10 cells high (Fig. 2F), and heterocellular with procumbent, square and upright cells. There are 1015 rays per $\mathrm{mm}$. Vessel-ray pits are centrally positioned on the cells and solitary (3-4 $\mu \mathrm{m}$ in diameter).

Morphotype C (Figs 2H-L)

Locality: Saint-André-d'Olérargues

Specimen number: AWSE-0006

Description: Wood is diffuse-porous and growth ring boundaries are indistinct or absent. Vessels are 35-60 $\mu \mathrm{m}$ in diameter and mainly solitary or radially grouped in 2 's or 3's (Figs 2H-I). Vessels have scalariform perforation plates with 5-10 bars (Fig. 2G) and small intervessel pits 4-5 $\mu \mathrm{m}$ in diameter. Vessel density is $20-25$ vessels per $\mathrm{mm}^{2}$. Fibres have simple pits (Fig. 2J). Vasicentric tracheids were observed. There is abundant paratracheal vasicentric axial parenchyma. Rays are 4-5 seriate, more than 30 cells high (Fig. 2H) and storeyed (Fig. 2K). Rays are weakly heterocellular with at least 1 row of marginal upright cells and there are small and multiple ray cell-to-ray cell pits (Fig. 2L). Vessel-ray pits were not observed.

Morphotype D (Figs 3A-C)

Locality: Saint-André-d'Olérargues

Specimen numbers: AWSE-0007; AWSE-0044

Description: Growth ring boundaries are indistinct or absent and the wood is diffuse-porous (Fig. 3A). Vessels are mainly solitary or radially grouped in 2's or 3's. Vessels are oval $(60-80 \times 130-150 \mu \mathrm{m})$ with scalariform perforation plates and a minimum of 10 bars (Fig. 3B). Intervessel pits are small, $4 \mu \mathrm{m}$ in diameter. Vessel density is 30-40 vessels per $\mathrm{mm}^{2}$. Fibres have simple pits, thin walls and some are septate. Abundant axial parenchyma is in narrow irregular bands ( 1 to 3 cells wide). Rays are heterocellular with procumbent cells and 1-2 rows of marginal upright cells, 1-2 seriate (Fig. 3C) and 8-13 cells high. Ray cell-to-ray cell pits are small and numerous. Vesselray pits were not observed.

\author{
Morphotype E (Figs 3D-G) \\ Localities: Saint-André-d'Olérargues; Le Pin \\ Specimen numbers: AWSE-0032; AWSE-0041
}

Description: Wood is diffuse-porous and growth ring boundaries indistinct or absent (Fig. 3D). Vessels are solitary to radially grouped in 2's or 3's, with scalariform perforation plates of more than 20 bars (Fig. 3E). Intervessel pits are small and mixed, alternate or opposite to scalariform. There are two sizes of vessels: narrow (30-50 $\mu \mathrm{m}$ in diameter) and large (70-100 $\mu \mathrm{m}$ in diameter). Vessel density is high (30-40 per $\left.\mathrm{mm}^{2}\right)$. Fibres have simple pits. Axial parenchyma is rare and badly preserved. Rays are heterocellular and narrow, 1-2 seriate (Fig. 3F). Ray height is 6-15 cells. Vessel-ray pits are simple and multiple (Fig. $3 \mathrm{G})$. The ray density is inestimable (at least $>5$ ).

Morphotype F (Figs 3H-J)

Locality: Saint-André-d'Olérargues

Specimen number: AWSE-0010

Description: Growth ring boundaries are indistinct or absent and the wood is diffuse-porous (Fig. 3H). Vessels are radially grouped in 3's or 4's, with scalariform plates (Fig. 3I). Opposite to scalariform intervessel pits are present. Vessels are narrow and slightly radially flattened $(35 \times 20 \mu \mathrm{m})$ and resemble tracheids. It is difficult to distinguish fibre-tracheids with alternate to opposite simple pits from vasicentric tracheids (Fig. 3J). Some fibres are septate. Axial parenchyma and rays are poorly preserved. Vessel-ray pits were not observed.

\section{Morphotype G (Figs 3K-L)}

Locality: Saint-André-d'Olérargues

Specimen numbers: AWSE-0022; AWSE-0025

Description: Diffuse-porous wood has indistinct or absent growth ring boundaries (Fig. 3K). Vessels are 70$140 \mu \mathrm{m}$ in diameter, solitary or grouped in 2's or 3's and with simple perforation plates. Reticulate small and large intervessel pits (Fig. 3L), 4-15 $\mu \mathrm{m}$, are without borders. There are 15-20 vessels per $\mathrm{mm}^{2}$. Thin-walled fibres with simple pits are abundant ( $4 \mu \mathrm{m}$ in diameter). Some septate fibres are also present. Axial parenchyma is rare and badly preserved. Rays are heterocellular with procumbent and square to upright cells, 2-5 seriate and fairly high (20-30 cells). Ray density was not measurable but appears high. Vessel-ray pits were not observed.

\section{Morphotype H (Figs 3M-N)}

Localities: Rodières; Saint-Laurent-de-Carnols

Specimen numbers: AWSE-0045; AWSE-0046; AWSE0056

Figure 2. Different anatomical features observed on woods from Gard. A-C: Type A. A: Transversal view. B: Scalariform plate. C: Details of ray cells and fibres. D-F: Type B. D: Transversal view. E: Tangential view showing a vessel with a simple perforation (bottom) and uni- to triseriate rays (top). F: Radial view of a ray. G-L: Type C. G: Scalariform plate. H: Transversal view. I: Detail of a group of 2 vessels. J: Detail of the fibre pits. K: Tangential view showing the storeyed rays. L: Details of the ray cells and of the ray cell-to-ray cell pits. 

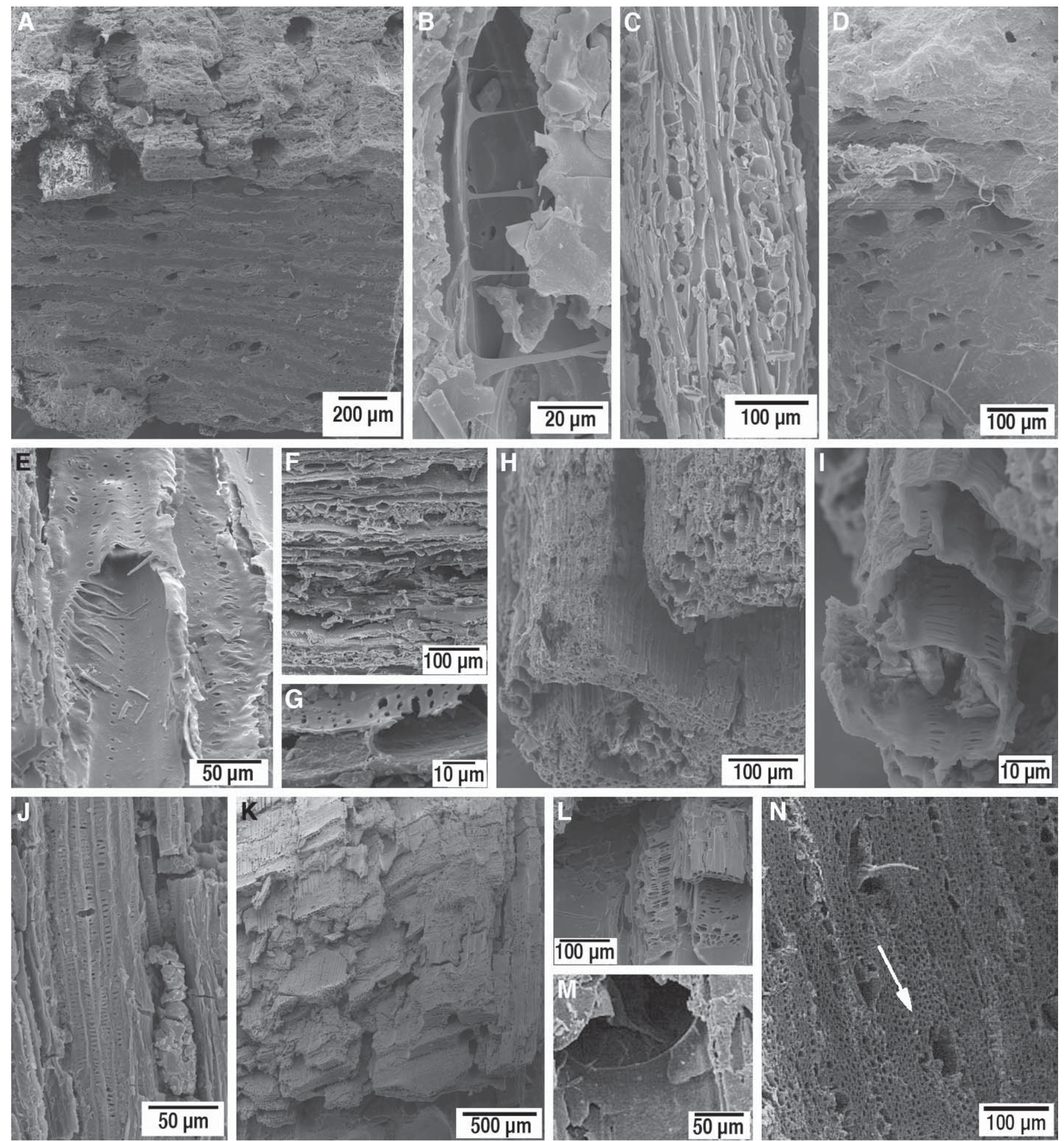

Figure 3. Different anatomical features observed on woods from Gard. A-C: Type D. A: Transversal view. B: Scalariform plate. C: Tangential view showing rays and fibres. D-G: Type E. D: Transversal view. E: Scalariform plate. F: Tangential view showing uni- to biseriate rays. G: Details of ray cells. H-J: Type F. H: Transversal view. I: Detail of a radial multiple of 3 vessels. J: Pits of the fibres. K-L: Type G. K: Transversal view. L: Perforation of the vessel plates. M-N: Type H. M: Simple perforation plate of the vessels. N: Transversal view showing vessels and axial parenchyma (white arrow). 
Description: Growth ring boundaries are indistinct or absent and wood diffuse-porous (Fig. 3N). Vessels are $80-110 \mu \mathrm{m}$ in diameter, solitary or grouped in 2's to 3's. Perforation plates are simple (Fig. $3 \mathrm{M}$ ). There are small, opposite intervessel pits (4 $\mu \mathrm{m}$ in diameter) and 10-15 vessels per $\mathrm{mm}^{2}$. Fibres have simple pits. Some septate fibres have been observed. Rare diffuse axial parenchyma is poorly preserved. Rays are 1-3 seriate, 20-25 cells high (Fig. $3 \mathrm{~N}$ ) and heterocellular with one row of marginal upright cells. Vessel-ray pits were not observed.

\section{Morphotype I (Figs 4A-B)}

Locality: Saint-André-d'Olérargues

Specimen number: AWSE-0021

Description: Semi-ring porous wood has growth ring boundaries indistinct or absent (Fig. 4A). Vessels are solitary or in radial multiples of 2-3-4 cells, with 3 sizes: small $(40-50 \mu \mathrm{m}$ in diameter), medium $(80-90 \mu \mathrm{m})$ and large $(140-150 \mu \mathrm{m})$. Perforation plates are scalariform and intervessel pits are small $(4 \mu \mathrm{m})$. Fibres with simple pits are present but a large proportion of the woody tissue comprises long cells with abundant spiral thickening (vascular tracheids?). Axial parenchyma is rare and diffuse. Rays are homocellular, mainly uniseriate and 3-5 cells high (Fig. 4B). Rays are equally spaced out (150$160 \mu \mathrm{m}$ between two rays). Ray density is low but could not be measured.
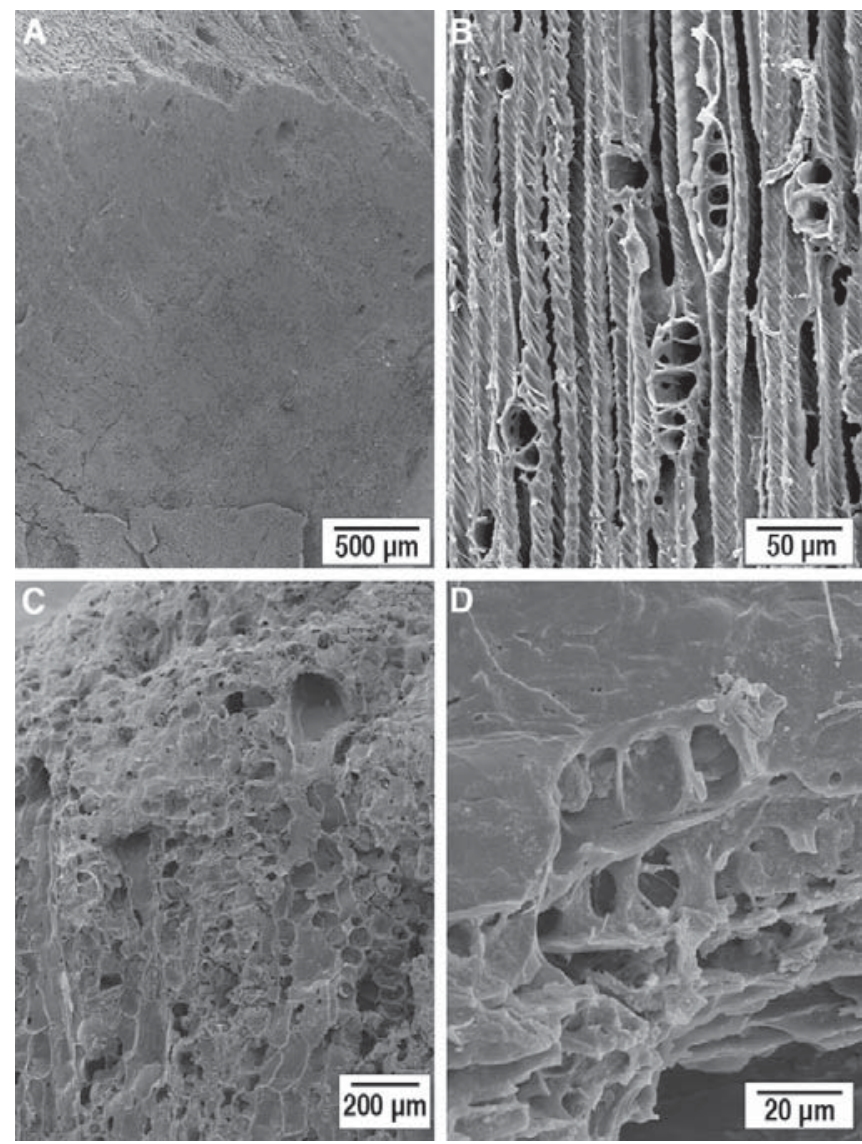

Morphotype J (Figs 4C-D)

Locality: Saint-Laurent-la-Vernède

Specimen number: AWSE-0011

Description: Diffuse-porous wood has growth ring boundaries indistinct or absent (Fig. 4C). Vessels are mostly solitary or in pairs and large, 170-200 $\mu \mathrm{m}$. Perforation plates were not observed. There are 10-15 vessels per $\mathrm{mm}^{2}$ and intervessel pits are small, $4 \mu \mathrm{m}$ in diameter. Fibre-tracheids are badly preserved with large bordered pits (Fig. 4D). Presence of diffuse axial parenchyma was noted. Rays are large, heterocellular, 10-15 seriate and 25-30 cells high.

\section{DISCUSSION}

\section{ANGIOSPERMS IN EARLY-MIDDLE CENOMANIAN PHYTOCENOSES OF GARD}

In the Gard localities the low percentage of angiosperm wood (Table 2) suggests that woody flowering plants probably occupied only a small part of the vegetation. A straightforward interpretation of the relative proportions of angiospermous and gymnospermous wood fragments, however, is risky mainly because of taphonomical and ecological biases (Martín-Closas \& Gomez, 2004).

All the angiosperm wood specimens studied were from axes of relatively small diameter (i.e., less than a few centimetres) when judged on ray divergence. Charring is known to induce shrinkage and distortion (McGinnes et al., 1971) so we consider that our specimens are not relevant to address the question of the habit of these angiosperms. Some xylological characters of these specimens, however, indicate the existence of already tall (undoubtedly shrubby, perhaps arborescent) angiosperms. Indeed, some woods have simple perforation plates, which was a character related to the development of a shrubby or arborescent habit in flowering plants (Wheeler \& Baas, 1991). It has been also observed abundant alternate intervessel pits, which Carlquist (1988) suggested as the consequence of robust vessel walls and interpreted as an indicator of high stature (shrub or arborescent) in angiosperms.

The nineteen angiosperm wood specimens from the Cenomanian of the five localities of Gard reveal a surprising diversity (Girard, 2005). On the basis of the xylological key by Suzuki et al. (1996), ten morphotypes (A-J above) have been distinguished. This diversity appears quite large as only six Aptian or Albian wood morphospecies were previously described worldwide.

Figure 4. Different anatomical features observed on woods from Gard. A-B: Type I. A: Transversal view. B: Tangential view. C-D: Type J. C: Transversal view. D: Pits of the fibres. 
Charcoal studies have been underrepresented for the investigation of early angiosperm evolution and systematics (Herendeen, 1991). Many of our specimens were only a few millimetres in size so some rare cell or perforation types may have been overlooked. This and the possible allometric modifications of cell dimensions during charring processes suggest that interpretation on diversity is not prudent.

\section{Angiosperm palaeoecology}

This study aimed to determine the potential of angiosperm charcoal for palaeoecological reconstruction, using narrow statistical correlations evidenced by Wheeler \& Baas (1991, 1993) and by Wiemann et al. (1998, 1999) between environmental conditions and qualitative to semiquantitative anatomical characters of angiosperm woods. Given the limitations mentioned above, inferences are discussed, considering wood characters one by one.

\section{Growth rings}

The absence of growth rings in the angiosperm wood specimens observed might indicate that a climate without marked seasons existed during the Early-Middle Cenomanian in Gard. Indeed, only living plants of rather uniform environments do not have growth rings (Wheeler \& Baas, 1991; Brison et al., 2001). However, we observed in the same localities similar-sized charcoal specimens that we identified to the Coniferales (Taxodioxylon Hartig, Podocarpoxylon Gothan) and the Ginkgoales (Ginkgoxylon Saporta), a small proportion of them having well-marked growth rings (6 out of 32 specimens, i.e., 15\%) (Fig. 3A). Three reasons can explain such a discrepancy during the Early-Middle Cenomanian in Gard: (1) although growth rings were produced by gymnosperms (endogenous control hypothesis), environmental conditions were uniform over the year; (2) although early angiosperms did not record a seasonality, there was a seasonality in temperature or rainfall (seasonal climate hypothesis); (3) the growth rings were not observed in angiosperm wood because of the small dimension of specimens (taphonomical bias hypothesis). Gymnosperm charcoal specimens found in the same fossil wood assemblage exhibit growth rings, while they are of similar size to the angiosperm charcoal specimens. This observation makes it plausible that the absence of growth rings in angiosperm charcoal is a primary signal, i.e., early angiosperms formed no rings, having a continuous growth (Poole, 1994).

The occurrence of growth rings in other woody plants (i.e., conifers or ginkgos) supports the seasonal climate hypothesis. Brison et al. (2001), however, showed that by the Mesozoic Taxodioxylon Hartig always produced growth rings, whatever the climate it was experiencing. Moreover, as the proportion of homoxylous wood specimens with growth rings is low compared to normal Mesozoic figures, we favour the endogenous control hypothesis for explaining the discontinuous growth observed in some gymnosperm specimens.

Falcon-Lang et al. (2001) described similar wood assemblages from the upper Middle Cenomanian of Czech Republic, gymnosperm charcoal having growth rings and

Table 3. Summary of the different studied anatomical characters and the palaeoecological inferences that can be made from each one.

\begin{tabular}{|c|c|c|c|c|}
\hline Wood features & State & \begin{tabular}{|c|} 
Climatological \\
inferences in modern \\
floras
\end{tabular} & $\begin{array}{l}\text { Climatically } \\
\text { informative }\end{array}$ & Probable interpretation \\
\hline Growth rings & mainly absent & $\begin{array}{l}\text { tropical with low } \\
\text { seasonnality }\end{array}$ & $\begin{array}{l}\text { partly } \\
\text { (seasonnality) }\end{array}$ & $\begin{array}{l}\text { rainfall seasonality possible if the } \\
\text { plants grew up on a well-watered } \\
\text { soil }\end{array}$ \\
\hline \multirow{2}{*}{ Porosity } & mainly diffuse & tropical & yes & \\
\hline & low density & tropical & yes & \\
\hline \multirow{4}{*}{ Vessels } & small diameter & temperate & no & Phylogenetically biased? ${ }^{1}$ \\
\hline & $\begin{array}{l}\text { scalariform } \\
\text { perforation plates }\end{array}$ & temperate to cold & no & Phylogenetically biased? ${ }^{1}$ \\
\hline & mainly isolated & temperate to cold & no & Phylogenetically biased ${ }^{1}$ \\
\hline & $\begin{array}{l}\text { occurrence of radial } \\
\text { groups of 2-3 pores } \\
\text { or clusters }\end{array}$ & hydric seasonality & yes & \\
\hline \multirow{3}{*}{ Fibres/tracheids } & $\begin{array}{l}\text { weak abundance of } \\
\text { fibre-tracheids }\end{array}$ & tropical & yes & preservational biases \\
\hline & $\begin{array}{l}\text { occurrence of } \\
\text { vasicentric tracheids }\end{array}$ & hydric seasonality & yes & \\
\hline & septate fibres rare & temperate & no & $\begin{array}{l}\text { phylogenetical or preservational } \\
\text { biases }\end{array}$ \\
\hline \multirow{2}{*}{$\begin{array}{c}\text { Axial } \\
\text { parenchyma }\end{array}$} & $\begin{array}{l}\text { mainly apotracheal } \\
\text { diffuse }\end{array}$ & temperate & no & Phylogenetically biased? ${ }^{1}$ \\
\hline & $\begin{array}{l}\text { some paratracheal } \\
\text { to vasicentric }\end{array}$ & tropical & yes & \\
\hline
\end{tabular}


angiosperm charcoal having none. They suggested that angiosperms grew in areas where water was usually available, such as riparian or amphibious vegetation, whereas gymnosperms occupied drier areas. The same explanation cannot stand for the Pauletian wood assemblage of Gard because of its peculiar depositional environment (i.e., a protected marsh or lagoon). Takahashi \& Suzuki (2003) observed distinct growth rings in most of the 266 gymnosperms and none in most of the 144 dicotyledonous angiosperms from the Cretaceous of Hokkaido. They concluded that the ability to form wood growth rings might have evolved quite late in the majority of the dicotyledons.

These growth ring results are not incompatible with some seasonality. Thus, should a clear thermal seasonality have occurred, both angiosperms and gymnosperms would have developed growth rings. However, a marked seasonality in rainfall climate is compatible with our observations, as long as soils remained well-watered (but not asphyxiating) year-round.

\section{Porosity}

The high percentage of diffuse porous angiosperm wood (18 out of 19 specimens) fits well with the image of a tropical climate in Gard during the Early-Middle Cenomanian. Today most tropical floras have a similar percentage, but it has been demonstrated that temperate southern hemisphere woody plants are also overwhelmingly diffuse porous (Wheeler et al., 2007). In cool temperate and cold floras a notable proportion of wood is characterised by ring or semi-ring porosity (Wheeler \& Baas, 1991; Boura \& De Franceschi, 2007), but Boura \& De Franceschi (2007) indicated that $28 \%$ of the 193 European species wood they studied were only diffuse porous. The occurrence of semiring porosity in one specimen (Fig. 3B) is not paradoxical. Even within the tropical belt, some angiosperms develop this feature when they are exposed to seasonal water stress (Wheeler \& Baas, 1991). Boura \& De Franceschi (2007) showed that most of the ring porous woods from tropical belt belong to deciduous species and that, in $90 \%$ of the woods, the character "ring porous" is associated with the character "simple perforation plates".

The low vessel density (between 15 and 25 vessels per $\mathrm{mm}^{2}$ ) of fossil angiosperm wood from the Lower-Middle Cenomanian of Gard also suggests a tropical climate at that time. Living angiosperms from temperate to cold environments generally have a higher density (more than 100 vessels per $\mathrm{mm}^{2}$ ) than those of tropical angiosperms (except for those growing in high altitude) (Wheeler \& Baas, 1991). The charring process may have increased the apparent vascular density, thus limiting the interpretation.

\section{Vessels: Diameter, lateral pitting and grouping}

Although the three characters considered previously point to a tropical climate (with probable seasonality of precipitation), other wood characters are contrary to this interpretation. Thus, we observe relatively small vessel diameters (on average). In extant floras warm-climate an- giosperms have larger vessels than those of cold climates (Wheeler \& Baas, 1991). In this respect shrinkage from charring is obviously inducing a certain bias (difficult to estimate). Statistical studies showed that narrow vessels $(\leq 100 \mu \mathrm{m})$ were more frequent during the Cretaceous (Wheeler \& Baas, 1991) and various data indicate that the Cenomanian was a warm period (Fluteau, 2003). Our observations confirm that for the Early-Middle Cenomanian floras, it is advisable not to use the character "vessel diameter" as a palaeoclimatic indicator.

Most perforation plates observed are scalariform. Today this type is encountered mostly from temperate to cold floras (Wheeler \& Baas, 1991). However, during the Cretaceous, scalariform perforation plates were clearly more widespread than today. About $60 \%$ of Cretaceous angiosperm wood morphospecies described have scalariform perforation plates compared to only $10 \%$ of angiosperms today (Wheeler \& Baas, 1991). Wheeler \& Baas (1991, 1993 ) interpreted this Cretaceous high percentage as a result of a phylogenetic bias, scalariform perforations being considered as primitive. We also observed specimens with simple perforation plates, which is a character state considered to be derived and which might fit well with a seasonally dry climate. Accordingly the development of simple perforation plates was correlated in some cases with water stress (Wheeler \& Baas, 1991).

Fossil angiosperm wood specimens studied have mostly solitary vessels, which may be formed in temperate and cold floras. Wheeler \& Baas (1991) demonstrated, however, that all Cretaceous angiosperm wood assemblages share a high proportion of isolated vessels. These results confirm that vessel grouping cannot be used for palaeoclimatic inferences for the Early-Middle Cenomanian and its high proportion observed may be considered as a phylogenetic bias.

Radial groups of 2-4 vessels are observed in twelve angiosperm specimens. Grouped vessels were rare during the Cretaceous and only reached significant importance during the Eocene (Wheeler \& Baas, 1991). According to Carlquist (1984), grouped vessels could correspond to "a device for hydraulic safety", thus ensuring a better sap transport during the dry season. Their relative abundance in the angiosperm woods from the Lower-Middle Cenomanian of Gard compared to other Cretaceous wood assemblages may indicate some seasonality.

\section{Fibres and Tracheids}

Fibres are badly preserved in most of the wood specimens described here. We observed septate fibres in only three morphotypes $(\mathrm{D}, \mathrm{G}$ and $\mathrm{H})$ and only in six specimens (31\% of the specimens). The lack of septate fibres among the other samples is surprising as those fibres are today more common in tropical environments and they were more frequent during the Cretaceous than today (Wheeler \& Baas, 1991). Two possibilities may explain this weak occurrence: (1) Early-Middle Cenomanian angiosperm flora of Gard was phylogenetically unusually low in sep- 
tate fibres; and (2) septate fibres were present originally but either not preserved or under-recognized (by the fact they are difficult to recognize under SEM in charcoals). It is advisable not to use septate fibres in our palaeoclimatic interpretation. Vasicentric and vascular tracheids are rare in the wood assemblage described here. Vasicentric tracheids have been observed in only one wood (morphotype C). Vascular tracheids are more common, being found in three specimens of three different morphotypes. These two kinds of tracheids were relatively rare during the Cretaceous (4\% of occurrence in the Northern $\mathrm{He}-$ misphere only) but became more common in modern floras subjected to seasonal drought conditions (Wheeler \& Baas, 1991). This xylological character fully argues for a tropical climate with alternations of rain and dry seasons during the Early-Middle Cenomanian in Gard. The weak occurrence of bordered pits (only two specimens of two different morphotypes exhibit fibre-tracheids) may indicate a relatively warm climate since the abundance of fibretracheids is a characteristic of a cool environment (Wheeler \& Baas, 1991).

\section{Axial parenchyma, rays}

Parenchymatous tissues of fossil angiosperm woods are difficult to interpret in terms of palaeoclimate (Kribs, 1935; Wheeler \& Baas, 1991, 1993). Ray parenchyma anatomical characters are not statistically correlated with environmental parameters for both modern and extinct wood assemblages (Wheeler \& Baas, 1991). We only noted the presence of one specimen with homocellular rays (morphotype I) and the presence of 1-2 rows of upright cells around the rays in three of the morphotypes $(\mathrm{C}, \mathrm{D}, \mathrm{H})$.

In the specimens studied axial parenchyma is rare and mainly diffuse (Fig. 3D). Today such an axial parenchyma distribution is more frequent in temperate environments than in tropical environments. Nevertheless diffuse parenchyma was very frequent (presence in $50 \%$ of the studied woods) during the Upper Cretaceous (Wheeler \& Baas, 1991). It may be due to a phylogenetical bias. However, the few occurrences of more elaborate parenchyma, paratracheal to vasicentric (Fig. 3E) and in narrow irregular bands, might indicate a tropical climate. These two types of parenchyma distribution, which are uncommon during the Cretaceous, are mainly found in the wood of tropical angiosperms today (Wheeler \& Baas, 1991).

\section{SYNTHESIS}

From our study, the image arises of a plant community, in a well watered (phreatic or meteoritic) environment, with angiosperms and gymnosperms growing together and endogenous cyclicity forming growth rings only in gymnosperms. It cannot be completely excluded, however, that early angiosperms had continuous growth in a changing environment. Very little is known about the physiology of continuous growth, but it was documented even in tropophilous environments where variation is in a warm range, 16 to $25^{\circ} \mathrm{C}$, see Jacoby (1989) and references therein.

The palaeoclimatic interpretations deduced from the anatomical study of angiosperm charcoal from the LowerMiddle Cenomanian of Gard (south France) match sedimentological and isotopic studies in seven characters, whereas they differ in the five remaining characters (Table 3). The vessel diameter, the occurrence of scalariform plates, the mainly isolated vessels, the rare septate fibres and the mainly apotracheal diffuse axial parenchyma were already used and interpreted by Wheeler \& Baas $(1991,1993)$ as being linked to a strong phylogenetic bias, at least during the Late Cretaceous. This study verifies that these five wood characters should not be applied to palaeoclimatic reconstructions for the early Late Cretaceous. In contrast, growth-rings, porosity type, porosity density, occurrence of vessel groups, occurrence of vasicentric tracheids and of some paratracheal to vasicentric and banded axial parenchyma suggest a tropical climate with low temperature seasonality and marked water seasonality. This matches well with sedimentological and isotopic evidence. The low abundance of fibre-tracheids also fits with sedimentological and isotopic studies. However, their abundance in our wood assemblage could be biased because of some preservational factors.

Many palaeofloras have been recently discovered in the Upper Cretaceous of Iberian Peninsula, among which angiosperms have a significant share (Friis et al., 2006; Villanueva-Amadoz et al., 2010). It would be of interest to search specifically for angiosperm wood within these strata. Their interpretation would help to investigate relationships between palaeoclimate and early angiosperm evolution, a much debated issue for which the Iberian Peninsula is a key-area.

\section{ACKNOWLEDGEMENTS}

The authors very gratefully thank Prof. Elisabeth Wheeler, Prof. Peter Baas and Dr. Jakub Sakala for their valuable help and comments on an earlier draft. Prof. InSung PAIK (South-Korea) helped us to interpret the sedimentology of several localities. The authors thank Dr. Silvia C. Gnaedinger (Argentina) for helping to translate the abstract into Spanish.

\section{REFERENCES}

Amiot, R., Lécuyer, C., Buffetaut, E., Fluteau, F., Legendre, S. \& Martineau, F. 2004. Latitudinal temperature gradient during the Cretaceous Upper Campanian-Middle Maastrichtian: $\delta^{18} \mathrm{O}$ record of continental Vertebrates. Earth and Planetary Sciences Letter, 226, 255-272. 
Anderberg, A.A., Rydin, C. \& Kallersjo, M. 2002. Phylogenetic relationships in the order Ericale s.1.: analyses of molecular data from five genes from the plasmid and mitochondrial genomes. American Journal of Botany, 89, 677-687.

Bailey, I.W. 1924. The problem of identifying the wood of Cretaceous and later dicotyledons: Paraphyllanthoxylon arizonense. Annals of Botany, 38, 439-451.

Barale, G., Barbacka M. \& Philippe, M. 2002. Early Cretaceous flora of Hungary and its palaeoecological significance. Acta Palaeobotanica, 42, 13-27.

Bornemann., A., Pross, J., Reichelt, K., Herrle, J.O., Hemleben C. \& Mutterlose, J. 2005. Reconstruction of short-term palaeoceanographic changes during the formation of the Late Albian 'Niveau Breistroffer' black shales (Oceanic Anoxic Event 1d, SE France). Journal of the Geolological Society, 162, 623-639.

Boura, A. \& De Franceschi, D. 2007. Is porous wood structure exclusive of deciduous trees? Comptes Rendus Palevol, 6, 385-391.

Brison, A.L., Philippe, M. \& Thévenard, F. 2001. Are Mesozoic growth ring patterns climate-induced? Palaeobiology, 27, 531-538.

Buurman, P. 1972. Mineralization of fossil wood. Scripta Geologica, 12, 1-43.

Carlquist, S. 1984. Vessel grouping in dicotyledon woods: significance and relationship to imperforate tracheary elements. Aliso, 10, 505-525.

Carlquist, S. (ed.) 1988. Comparative Wood Anatomy: Systematic, Ecological, and Evolutionary Aspects of Dicotyledon Wood. Springer Verlag, Berlin.

Crawley, M. 2001. Angiosperm woods from British Lower Cretaceous and Palaeogene deposits. Special Papers in Palaeontology, 66, 1-100.

Defretin, S. 1943. Etude pétrographique du lignite cénomanien de Saint-Paulet-de-Caisson (Gard). Bulletin de la Société Géologique de France, 13, 489-497.

De La Fuente, M., Philippe, M. \& Lozano, R.P. 2008. La colección de troncos fósiles mesozoicos españoles del Museo Geominero (IGME, Madrid). The XXIV ${ }^{\text {as }}$ Jornadas de la Sociedad Española de Paleontología, Abstract Book, p. 101-103.

Donnadieu, Y., Pierrehumbert, R., Jacob, R. \& Fluteau, F. 2006. Modelling the primary control of palaeogeography on Cretaceous climate. Earth and Planetary Sciences Letters, 248, 426-437.

Ducreux, J.L. 1982. Recherche des concentrations métallifères en domaine paralique et limnique. Le cas des formations Crétacé supérieur gardois, du Paléogène de Manosque (Alpes-de-Haute-Provence) et de Saint-Martin-de-Palins (Puy-de-Dômes). PhD Thesis, Université Claude Bernard Lyon 1 (unpublished).

Ducreux, J.L. 1989. La transgression lagunaire d'âge cénomanien moyen à supérieur le long de la bordure cévenole (bassin du Sud-Est de la France); Apports de la minéralogie et de la géochimie. Geobios, 22, 27-33.

Ducreux, J.L. \& Gaillard, M.G. 1986. Le Cénomanien moyen à lignite de Saint-Laurent-de-Carnols (Gard). Données palynologiques et sédimentologiques. Implications paléoécologiques. Géologie de la France, 2, 189-196.

Duparque, A. 1926. Le rôle des tissus lignifiés dans la formation de la houille. Annales de la Société Géologique du Nord, LI, 51-64.

Falcon-Lang, H.V., Kvaček, J. \& Uličný, D. 2001. Fire-prone plant communities and palaeoclimate of a Late Cretaceous fluvial to estuarine environment, Pecínov, Czech Republic. Geological Magazine, 138, 562-576.

Figueiral, I. 1999. Lignified and charcoalified fossil wood. In: Fossil Plants and Spores: Modern Techniques (eds. Jones, T.P. \& Rowe, N.P.). The Geological Society, London, 92-96.

Figueiral, I., Mosbrugger, V., Rowe, N.P., Utescher, T., Jones, T.P. \& Von Der Hocht, F. 2002. Role of charcoal analysis for interpreting vegetation change and paleoclimate in the Miocene Rhine Embayment (Germany). Palaios, 17, 347-365.

Fluteau, F. 2003. Earth dynamics and climate changes. Comptes Rendus Geosciences, 325, 157-174.

Friis, E.M., Pedersen, K.R. \& Crane, P.R. 2006. Cretaceous angiosperm flowers: Innovation and evolution in plant reproduction. Palaeogeography, Palaeoclimatology, $\mathrm{Pa}$ laeoecology, 232, 251-293.

Gaillard, M.G. 1982. Etude palynologique de gisements à lignite du Crétacé supérieur du département du Gard. Stratigraphie - Paléontologie. PhD Thesis, Université Claude Bernard Lyon1 (unpublished).

Gerards, T., Damblon, F., Wauthoz, B. \& Gerrienne, P. 2007. Comparison of cross-field pitting in fresh, dried and charcoalified softwoods. IAWA Journal, 28, 49-60.

Girard, V. 2005. Diversité des bois et paléoécologie d'Angiospermes basales dans le Cénomanien (Crétacé) du Gard (France). Master Thesis, Université Claude Bernard Lyon1 (unpublished).

Gryc, V., Vavrčik, H. \& Sakala, J. 2009. Cenomanian angiosperm wood from the Bohemian Cretaceous Basin, Czech republic. IAWA Journal, 30, 319-329.

Herendeen, P.S. 1991. Charcoalified angiosperm wood from the Cretaceous of eastern North America and Europe. Review of Palaeobotany and Palynology, 70, 225-239.

Herrle, J.O., Pross, J., Friedrich, O. \& Hemleben, C. 2003a. Short-term environmental changes in the Cretaceous tethyan ocean: micropalaeontological evidence from the early Albian oceanic anoxic event 1b. Terra Nova, 15, 14-19.

Herrle, J.O., Pross, J., Friedrich, O., Koßler, P. \& Hemleben, C. 2003b. Forcing mechanisms for mid-Cretaceous black shales formation: evidence from the Upper Aptian and Lower Albian of the Vocontain Basin (SE France). Palaeogeography, Palaeoclimatology, Palaeoecology, 190, 399-426.

Jacoby, G.C. 1989. Overview of tree ring analysis in tropical regions. IAWA Bulletin, 10, 99-108.

Kribs, D. 1935. Salient lines of structural specialization in the wood ray of Dicotyledons. Botanical Gazette, 96, $547-557$. 
Martín-Closas, C. \& Gomez, B. 2004. Taphonomie des plantes et interprétations paléoécologiques. Une synthèse. Geobios, 37, 65-88.

McGinnes, E.A.Jr., Kandeel, S.A. \& Szopa, P.S. 1971. Some structural changes observed in the transformation of wood into fibre. Wood Fibre Sciences, 3, 77-83.

Page, V.M. 1979. Dicotyledonous wood from the Upper Cretaceous of central California. Journal of the Arnold Arboretum, 60, 323-349.

Page, V.M. 1980. Dicotyledonous wood from the Upper Cretaceous of central California. II. Journal of the Arnold Arboretum, 61, 723-748.

Page, V.M. 1981. Dicotyledonous wood from the Upper Cretaceous of central California. III. Conclusions. Journal of the Arnold Arboretum, 62, 437-455.

Philippe, M., Gomez, B., Girard, V., Coiffard, C., DavieroGomez, V., Thévenard, F., Billon-Bruyat, J.-P., Guiomar, M., Latil, J.-L., Le Loeuff, J., Néraudeau, D., Oliveri, D. \& Schlögl, J. 2008. Woody or not woody? Searching for first angiosperm wood in the Early Cretaceous of Europe. Palaeoworld, 17, 142-152.

Poole, I. 1994. Twig wood anatomical characters as palaeoecological indicators. Review of Palaeobotany and Palynology, 81, 33-52.

Poole, I. 2000. Fossil angiosperm wood anatomy: its role in the reconstruction of biodiversity and palaeoenvironment. Botanical Journal of the Linnean Society, 134, 361-381.

Poole, I. \& Van Bergen, P.F. 2006. Physiognomic and chemical characters in wood as paleoclimate proxies. Plant Ecology, 182, 175-105.

Prior, J. \& Gasson, P. 1993. Anatomical changes on charring six African hardwoods. IAWA Journal, 14, 77-86.

Pruvost, P. 1942. Un bassin houiller paralique d'âge cénomanien: les lignites de Pont-Saint-Esprit. Bulletin de la Société Géologique de France, 12, 165-180.

Pucéat, E., Lécuyer, C., Sheppard, S.M.F., Dromart, G., Reboulet, S. \& Grandjean, P. 2003. Thermal evolution of Cretaceous Tethyan marine waters inferred from oxygen isotope composition of fish tooth enamels. Paleoceanography, 18, 7.1-7.11.

Sakala, J. 2000. Silicified angiosperm wood from the Dangu locality (Ypresian of the Gisors region, Eure, France) final part: the problem of palaeoclimate reconstruction based on fossil wood. Geodiversitas, 22, 493-507.

Sander, P.M. \& Gee, C.T. 1990. Fossil charcoal: techniques and applications. Review of Palaeobotany and Palynology, 63, 269-279.

Scott, A.C. 1990. Anatomical preservation of fossil plants. In: Palaeobiology a Synthesis (eds. Briggs, D.E. \& Crowther, P.R.). Blackwell Scientific Publications, Oxford, 263-266.

Sellwood, B.W., Price, G.D., Shackleton, N.J. \& Francis, J. 1993. Palaeoclimates and their Modelling with Special Reference to the Mesozoic Era. Philosophical Transaction of the Royal Society B, 341, 225-233.

Siurek, J., Chevallier, P., Ro, C.-U., Chun, H.Y., Youn, H.S., Zięba, E. \& Kuczumow, A. 2004. Studies on the wood tissue substitution by silica and calcite during the preservation of fossil wood. Journal of Alloys and Compounds, 362, 107-115.

Slocum, D.H., McGinnes, E.A.Jr. \& Beall, F.C. 1978. Charcoal yield, shrinkage, and density changes during carbonisation of oak and hickory wood. Wood Sciences, 11, 4-47.

Suzuki, M. 1982. Some fossil woods from the Palaeogene of Northern Kyushu, II. The Botanical Magazine, Tokyo, 95, 281-294.

Suzuki, M., Noshiro, S. \& Tobe, H. 1996. Wood structure of Japanese Mesozoic Dicotyledons. In: Recent Advances in Wood Anatomy (eds. Donaldson, L.A., Singh, A.P., Butterfield, B.G. \& Whitehouse, L.). NZFRI Ltd, Rotorua, $150-158$.

Takahashi, K. \& Suzuki, M. 2003. Dicotyledonous fossil wood flora and early evolution of wood characters in the Cretaceous of Hokkaido, Japan. IAWA Journal, 24, 269-309.

Upchurch, G.R.Jr. \& Wolfe, J.A. 1987. Mid-Cretaceous to Early Tertiary vegetation and climate: Evidence from fossil leaves and wood. In: The Origins of the Angiosperms and Their Biological Consequences (eds. Friis, E.M., Chaloner, W.G. \& Crane, P.R.). Cambridge University Press, Cambridge, 75-105.

Videt, B., 2004. Dynamiques des paléoenvironnements à huîtres du Crétacé supérieur nord-aquitain (SO France) et du Mio-Pliocène andalou (SE Espagne). Mémoires Géosciences Rennes, 108, 1-261.

Villanueva-Amadoz, U., Pons, D., Diez, J.B., Ferrer, J. \& Sender, L.M. 2010. Angiosperm pollen grains of San Just site (Escucha Formation) from the Albian of the Iberian Range (north-eastern Spain). Review of Palaeobotany and Palynology, 162, 362-381.

Voigt, S., Wilmsen, M., Mortimore, R.N. \& Voigt, T. 2003. Cenomanian palaeotemperature derived from the oxygen isotopic composition of brachiopods and belemnites: evaluation of Cretaceous palaeotemperature proxies. International Journal of Earth Sciences, 92, 285-299.

Wheeler, E.A. 1991. Paleocene dicotyledonous trees from Big Bend National Park, Texas: Variability in wood types common in the Late Cretaceous and Early Tertiary, and ecological inferences. American Journal of Botany, 78, 658-671.

Wheeler, E.A. \& Baas, P. 1991. A survey of the fossil record for Dicotyledonous wood and its significance for evolutionary and ecological wood anatomy. IAWA Bulletin n.s., 12, 275-332.

Wheeler, E.A. \& Baas, P. 1993. The potentials and limitations of dicotyledonous wood anatomy for climatic reconstructions. Paleobiology, 19, 487-498.

Wheeler, E.A. \& Lehman, T.M. 2009. New Late Cretaceous and Paleocene dicot woods of Big Bend National Park, Texas, and review of Cretaceous woods characteristics. IAWA Journal, 30, 293-318.

Wheeler, E.A., Baas, P. \& Rodgers, S. 2007. Variations in dicot wood anatomy - A global analysis based on the Inside Wood database. IAWA Journal, 28, 229-258. 
White, T., Gonzalez, L., Ludvigson, V. \& Poulsen, C. 2001. Middle Cretaceous greenhouse hydrologic cycle of North America. Geology, 29, 363-366.

Wiemann, M.C., Wheeler, E.A., Manchester, S.R. \& Portier, K.M. 1998. Dicotyledonous wood anatomical characters as predictors of climate. Palaeogeography, Palaeoclimatology, Palaeoecology, 139, 83-100.

Wiemann, M.C., Manchester, S.R. \& Wheeler, E.A. 1999. Paleotemperature estimation from dicotyledonous wood characters. Palaios, 14, 460-474.
Willis, K.J. \& McElwain, J.C. 2002. Flowering plant origins. In: The Evolution of Plants (eds. Willis, K.J. \& McElwain, J.C.). Oxford University Press, Oxford, 156-193.

Wing, S.L. \& Boucher, L.D. 1998. Ecological aspects of the Cretaceous flowering plant radiation. Annual Review of Earth and Planetary Sciences, 26, 379-421.

Manuscrito recibido: 18 de abril, 2011 Manuscrito aceptado: 3 de noviembre, 2011 
